\title{
Keluhan Kesehatan Subjektif Pada Masyarakat Pengguna Insektisida Antinyamuk di Kecamatan Indralaya
}

\author{
Imelda Gernauli Purba ${ }^{*}$, Elvi Sunarsih ${ }^{1}$, Dwi Septiawati ${ }^{1}$, Rico Januar Sitorus ${ }^{2}$,Widya Lionita ${ }^{3}$ \\ ${ }^{1}$ Departemen Kesehatan Lingkungan Fakultas Kesehatan Masyarakat Universitas Sriwijaya \\ 2 Departemen Epidemiologi Fakultas Kesehatan Masyarakat Universitas Sriwijaya \\ ${ }^{3}$ Departemen Promosi Kesehatan Fakultas Kesehatan Masyarakat Universitas sriwijaya \\ *Corresponding author: imeldapurba7@gmail.com
}

Info Artikel : Diterima 18 September 2019 ; Disetujui 2 Februari 2020 ; Publikasi 1 April 2020

\begin{abstract}
ABSTRAK
Latar belakang: Antinyamuk merupakan insektisida yang banyak digunakan di rumah tangga untuk mengendalikan nyamuk. Penanganan yang tidak baik terhadap antinyamuk dapat membahayakan manusia dan lingkungan. Tujuan penelitian ini adalah menganalisis hubungan pajanan insektisida antinyamuk dengan keluhan kesehatan subjektif pada masyarakat di Kecamatan Indralaya

Metode: Penelitian ini adalah analitik dengan pendekatan cross sectional. Sampel diambil sebanyak 136 orang pengguna antinyamuk secara cluster sampling. Variabel bebas penelitian ini adalah umur, Indeks Massa Tubuh, pengetahuan, personal higiene, penggunaan sesuai petunjuk, cara penyimpanan, penggunaan alat pelindung diri, frekuensi pemakaian, dan durasi pemakaian. Pengumpulan data melalui wawancara menggunakan kuesioner dan observasi menggunakan checklist. Pengolahan dan analisis data dilakukan dengan bantuan software, data dianalisis dengan uji statistik Chi-Square dan regresi logistik.

Hasil: Hasil penelitian menunjukkan sebesar 58,1 \% reponden mengalami keluhan kesehatan subjektif yaitu sakit kepala, lelah, pusing, gatal pada mata, penglihatan kabur, hilang selera makan, kejang otot, tremor, sesak nafas, mata berair, keringat berlebihan. Berdasarkan hasil uji Chi-square terdapat hubungan yang signifikan antara umur ( $\mathrm{p}=0,015 ; \mathrm{RP}=0,36 ; 95 \% \mathrm{CI}=0,158-0,819)$, durasi pemakaian $(\mathrm{p}=0,032$; $\mathrm{RP}=2,96 ; 95 \% \mathrm{CI}=1,099$ 7,975), tingkat pengetahuan ( $\mathrm{p}=0,000 ; \mathrm{RP}=0,211 ; 95 \% \mathrm{CI}=0,089-0,499)$ dengan keluhan kesehatan subjektif.

Simpulan: Disimpulkan bahwa durasi pemakaian antinyamuk dalam sehari menjadi faktor risiko dominan untuk terjadinya keluhan kesehatan subjektif pada masyarakat pengguna antinyamuk di Kecamatan Indralaya Ogan Ilir.
\end{abstract}

Kata kunci: atinyamuk; durasi pemakaian; keluhan kesehatan subjektif

\section{ABSTRACT}

Title: Subjective Health Complaints In Communities Anti-Mosquito Insecticides User In Indralaya Sub-District Background: Anti-mosquito is an insecticide that is widely used in households to control mosquitoes. Handling that is not good against mosquitoes can harm humans and the environment. The objective of this study was to analyze the relationship between anti-mosquito insecticide exposure and subjective health complaints in the Indralaya District community

Methods: This study was an analytical with cross-sectional approach. Samples were taken as many as 136 anti-mosquito users by cluster sampling. The independent variables of this study were age, body mass index, knowledge, personal hygiene, usage according to instruction, use of personal protective equipment, frequency of use, and duration of use. Collecting data was through interviews using questionnaires, and observations using a checklist. Processing data was performed using software. Data were analyzed by Chi-square test at 0.05 level of significant.

Results: Research result showed that 58,1\% respondents experienced subjective health complaints such as headache, fatique, dizziness, itching in the eyes, blurred vision, loss of appetite, muscle spasm, tremors, shortness of breath,watery eye, and excessive sweating. Based on Chi-square test resut there was significant 
relationship between age ( $p=0.015 ; R P=0.36 ; 95 \% C I=0.158-0.819)$, duration of use ( $p=0.032 ; R P=2.96$; $95 \% C I=1.099-7.975)$, knowledge $(p=0,000 ; R P=0,211 ; 95 \% C I=0,089-0,499)$ with subjective health complaints

Conclusion: It was concluded that the duration of anti-mosquito use in a day was the dominant risk factor for the occurrence of subjective health complaints on mosquito users in Indralaya Ogan Ilir.

Keywords: Anti-mosqito; duration of use; subjective health cmplaints

\section{PENDAHULUAN}

Penggunaan insektisida antinyamuk di rumah tangga sekarang ini senantiasa meningkat, dimana penggunaan insektisida merupakan proporsi tertinggi dalam upaya mengendalikan vektor nyamuk dibandingkan dengan upaya lainnya seperti penggunaan kelambu. ${ }^{1}$ Beberapa hasil penelitian menyebutkan bahwa insektisida antinyamuk digunakan dalam mengendalikan vektor penyakit seperti penyakit malaria dan Demam Berdarah Dengue (DBD), diperoleh $43,1 \%$ responden menggunakan antinyamuk dalam pemberantasan malaria, dan 75,67\%) menggunakan antinyamuk dalam pemberantasan DBD. $^{2,} \quad 3 \quad$ Penggunaan antinyamuk bakar di rumah tangga memiliki proporsi $48,4 \%$, repelen $(16,9 \%)$, insektisida $(12,2 \%)$. Proporsi penggunaan anti nyamuk bakar lebih tinggi di pedesaan $(50,0 \%)$ daripada perkotaan $(46,9 \%)$. Sementara proporsi penggunaan repellent $(23,2 \%)$ dan insektisida $(17,9 \%)$ lebih tinggi di perkotaan dibanding di pedesaan dimana penggunaan repelent $10,4 \%$ dan insektisida $6,4 \%$. Proporsi rumah tangga yang menyimpan pestisida/insektisida di rumah tangga di Indonesia 20,2\%., di daerah perkotaan lebih tinggi proporsinya ( $20,5 \%$ ) dibanding di daerah pedesaan $(19,9 \%){ }^{1}$

Berdasarkan hasil penelitian penggunaan insektisida antinyamuk menunjukkan intensitas yang tinggi di berbagai daerah di Indonesia. Data hasil penelitian menjelaskan di Daerah Khusus Ibu Kota (DKI) Jakarta, penggunaan antinyamuk dalam mengendalikan vektor nyamuk mencapai $80 \%$. Jenis antinyamuk yang digunakan adalah antinyamuk semprot sebesar 36,6\%, insektisida bakar 14,8\%, antinyamuk oles $15,6 \%$, dan $12 \%$ menggunakan antinyamuk elektrik, serta $12,3 \%$ menggunakan kombinasi insektisida bakar, oles dan semprot. $^{3}$ Kusumastuti (2014) menyebutkan $82 \%$ rumah tangga di Desa Pangandaran menggunakan antinyamuk setiap hari, $59 \%$ yang sudah menggunakannya selama lebih dari sepuluh tahun, $62 \%$ menggunakan hanya satu jenis anti nyamuk, 19,4\% menggunkan jenis antinyamuk oles, dan $46 \%$ menyatakan penggunaan antinyamuk karena alasan kenyamanan. ${ }^{4}$

Antinyamuk merupakan insektisida yang terdiri dari beberapa senyawa kimia. Bahan aktif yang terkandung dalam antinyamuk tergolong bahan berbahaya dan atau beracun B(3). Antinyamuk mengandung senyawa kimia berbahaya bagi kesehatan manusia baik dalam bentuk cair (disemprotkan), maupun bakar yaitu propoxur, transflutrin, bioaleterin, dikiorvos, dalletherine, octachiorophil eter. ${ }^{5}$ Tingkat toksisitas dari setiap bahan aktif yang terdapat dalam insektisida antinyamuk ini tentu berbeda-beda. Hal ini menyebabkan tingkat efek keracunan yang ditimbulkan juga akan berbeda, yang juga dipengaruhi oleh intensitas pemakaiannya. Efek negatif yang timbul bisa secara akut jika pemajanan dengan intensitas yang sangat tinggi, dan bisa efek kronis dengan pemajanan pada intensitas rendah pada jangka waktu yang lama.

Meningkatnya penggunaan pestisida kimia telah menyebabkan kecemasan di kalangan masyarakat luas sebab pestisida dapat menimbulkan dampak negatif terhadap manusia dan lingkungannya. Dampak yang terjadi tidak hanya berpengaruh terhadap spesies sasaran saja, namun berpengaruh juga terhadap ekosistem setempat sebagai akibat dari penggunaan pestisida yang kurang hati-hati. ${ }^{6}$ Antinyamuk yang terhirup lewat saluran pernafasan pada jangka waktu lama menyebabkan perubahan atau kerusakan pada jaringan penyusun saluran pernafasan, mengakibatkan terganggunya fungsi jaringan-jaringan dalam sistem pernafasan. Selain pada efek pada saluran pernafasan, efek lainnya adalah pada kulit yang sangat tergantung sensitifitas kulit. Penggunaan antinyamuk yang tidak terkontrol menjadi faktor risiko terjadinya gangguan pada organ tubuh manusia. Jika orang dengan riwayat alergi terpajan pada antinyamuk secara intens lebih cepat terjadi reaksi. Saluran pernafasan menjadi bagian tubuh yang lergi yang paling banyak muncul biasanya mengenai saluran nafas sehingga menimbulkan batuk. $^{5}$

Penggunaan antinyamuk merupakan salah satu cara yang paling dipilih untuk menghindari gigitan nyamuk, dibandingkan cara lainnya oleh masyarakat di Kecamatan Indralaya. Data hasil penelitian sebelumnya pada ibu rumah tangga di Kecamatan Indralaya, menunjukkan terdapat sebesar $81,3 \%$ responden menggunakan antinyamuk bakar, $26,7 \%$ menggunakan antinyamuk cair, 18,7\% Repelent, serta $4,7 \%$ elektrik. Antinyamuk bakar menjadi jenis yang paling sering digunakan $(81,3 \%)$. Diantara responden ada yang menggunakan antinyamuk lebih dari 2 (dua) jenis secara bersamaan sebesar $28,7 \%$, bahkan menggunakan 3 jenis secara bersamaan $(3,3 \%)^{7}$ Kondisi seperti ini tentu dapat meningkatkan risiko terjadinya keracunan yang bersifat akut maupun efek kronis yaitu timbulnya keluhan atau gangguan kesehatan. Bertolak dari permasalahan ini, ingin 
dilakukan penelitian untuk mengetahui pajanan insektisida antinyamuk sebagai faktor risiko timbulnya keluhan kesehatan subjektif pada masyarakat di Kecamatan Indralaya Ogan Ilir.

\section{MATERI DAN METODE}

Penelitian ini dilakukan di Kecamatan Indralaya Kabupaten Ogan Ilir. Penelitian ini merupakan jenis analitik dengan pendekatan cross sectional. Pada Desain Cross Sectional pengukuran terhadap variabel bebas (independen) dengan variabel terikat (dependen) dilakukan dalam waktu yang bersamaan. Populasi penelitian ini adalah seluruh masyarakat yang tinggal menetap sebagai penduduk di Kecamatan Indralaya. Sampel penelitian ini adalah sebagian masyarakat yang tinggal di Kecamatan Indralaya yang diambil secara Cluster Sampling. Jumlah desa yang diambil secara random adalah sebanyak 4 desa $(20 \%)$ dari 20 desa yang terdapat di Kecamatan Indralaya, meliputi Desa Indralaya Mulia, Desa Indralaya Raya, Desa Tanjung Seteko dan Desa Muara Penimbung Ulu kemudian responden diambil secara acak dari setiap desa. Besar sampel yang diambil berdasarkan rumus perhitungan uji hipotesis beda proporsi populasi adalah sebanyak 136 responden. Responden adalah salah satu dari anggota rumah tangga dengan kriteria berumur $\geq 15$ tahun, mampu berkomunikasi dengan baik, dan menggunakan antinyamuk.

Variabel independen penelitian ini adalah umur, tingkat pendidikan, tingkat pengetahuan, IMT, durasi pemakaian antinyamuk, frekuensi pemakaian antinyamuk, penggunaan sesuai petunjuk, personal higiene, cara penyimpanan antinyamuk, penggunaan alat pelindung diri, jumlah jenis antinyamuk, dan variabel dependen adalah keluhan kesehatan subjektif.

Pengumpulan data dilakukan melalui wawancara menggunakan kuesioner untuk variabel umur, tingkat pendidikan, tingkat pengetahuan, durasi pemakaian antinyamuk, frekuensi pemakaian antinyamuk, penggunaan sesuai petunjuk, personal higiene, penggunaan APD, jumlah jenis antinyamuk, dan keluhan kesehatan subjektif. Pengumpulan data dengan observasi juga dilakukan untuk variabel cara penyimpanan antinyamuk dan jumlah jenis antinyamuk dengan membuat indikator menggunakan checklist. Data variabel Indeks Massa Tubuh diperoleh melalui pengukuran berat badan menggunakan timbangan badan dan tinggi badan menggunakan Mikrotoise.

Pengolahan data dimulai dengan tahapan editing yaitu memeriksa konsistensi data yaitu lengkap, benar dan relevan. Tahapan berikutnya adalah coding yaitu memberi kode pada data dalam bentuk angka agar mudah dimasukkan ke dalam media pengolahan data, lalu entry data. Skoring dilakukan pada beberapa variabel independen (tingkat pengetahuan, personal higiene, dan cara penyimpanan antinyamuk) untuk menentukan hasil ukurnya. Indeks Massa Tubuh dihitung dengan membagi berat badan dalam satuan kilogram dengan kuadrat tinggi badan dalam satuan meter, dengan kategori: 1.Kurus jika IMT $<18,5 ; 2$. Normal jika IMT 18,5-24; 3. Berat badan lebih jika IMT $\geq 25$. Penggunaan APD dikategorikan "tidak" jika tidak memakai sarung tangan dan masker; kategori "ya" jika memakai sarung tangan dan masker

pada saat aplikasi (menyemprotkan antinyamuk cair dan atau membakar antinyamuk bakar). Tingkat pendidikan dikategorikan" rendah" jika tidak tamat SD, tamat SD, dan tamat SLTP; tingkat pendidikan tinggi jika tamat SLTA dan PT. Keluhan kesehatan subjektif dikategorikan "ada" jika merasakan minimal 3 gejala dan "tidak ada" jika merasakan kurang dari 3 gejala diantara beberapa gejala spesifik akibat pajanan insektisida antinyamuk. Gejala spesifik yang timbul akibat pajanan insektisida antara lain penglihatan kabur,produksi ludah meningkat, keluar air berlebihan dari hidung, keluar air yang berlebihan dari mata, dan tremor

Pengolahan dan nalisis data menggunakan bantuan software. Metode yang digunakan untuk menganalisis faktor risiko keluhan kesehatan subjektif akibat pajanan insektisida antinyamuk adalah analisis bivariat menggunakan uji statistik Chi-square test pada taraf nyata $\alpha=0,05$. Selain itu dilakukan juga analisis terhadap resiko melalui perkiraan besar risiko terjadinya keluhan kesehatan subjektif dengan menghitung nilai Prevalence Ratio (PR) pada 95\% Confidence Interval $(95 \% \mathrm{CI})$. Analisis bivariat dilanjutkan dengan analisis multivariat menggunakan regresi logistik untuk mengetahui faktor yang paling dominan sebagai faktor risiko keluhan kesehatan subjekif dan untuk mengontrol variabel perancu.

\section{HASIL DAN PEMBAHASAN}

Karakteristik subjek berdasarkan umur terlihat tidak jauh berbeda proporsinya antara umur tua dan umur muda dimana selisih proporsinya hanya $13,2 \%$. Jenis kelamin subjek mayoritas perempuan ( $75,5 \%)$, dan lebih banyak dengan tingkat pendidikan rendah (69\%). Status Indeks Massa Tubuh (IMT) sebagian besar subjek berada pada status lebih (gemuk) yakni sebesar $80 \%$. Intensitas pajanan antinyamuk terhadap subjek dilihat dari beberapa faktor diantaranya durasi pemakaian antinyamuk sebagian besar $<8$ jam $(80,1 \%)$, frekuensi pemakaian antinyamuk sebagian besar $\leq 1$ kali $(88,2 \%)$. Subjek yang menggunakan antinyamuk tidak sesuai petunjuk $(65,4 \%)$, subjek yang memiliki tingkat pengetahuan kurang baik proporsinya lebih besar $(61,8 \%)$, namun personal higiene subjek saat kontak dengan antinyamuk seperti tidak makan, tidak minum atau tidak merokok saat mengaplikasikan antinyamuk sebagian besar sudah baik $(60,3 \%)$. Perilaku penyimpanan antinyamuk oleh subjek cenderung masih kurang baik (62,5\%), demikian halnya dengan kelengkapan alat pelindung diri saat aplikasi antinyamuk mayoritas subjek belum menggunakannnya secara lengkap $(68,4 \%)$. 
Keluhan subjektif sehubungan dengan pajanan bahan aktif insektisida antinyamuk yang dialami oleh subjek diantaranya adalah sakit kepala $(22,1 \%)$, lelah $(19,9)$, pusing $(19,9 \%)$, gatal pada mata $(17,65 \%)$, penglihatan kabur $(17,6 \%)$, hilang selera makan $(13,9 \%)$, kejang otot $(11,8 \%)$, tremor $(11,8 \%)$, sesak nafas $(10,3 \%)$, mata berair $(10,3 \%)$, keringat berlebihan $(10,3 \%)$, dan susah bernafas (9,6\%). Pada studi ini, subjek dikategorikan mengalami keluhan subjektif jika merasakan minimal 3 gejala diantara beberapa gejala spesifik akibat pajanan terhadap bahan aktif insektida yang terkandung dalam antinyamuk, sehingga didapatkan subjek yang mengalami keluhan kesehatan subjektif sebesar $58,1 \%$.

Subjek pada golongan umur dewasa cenderung memiliki proporsi yang lebih tinggi $(48,1 \%)$ mengalami keluhan subjektif dengan keluhan subjektif dibanding umur yang lebih tua 33,9\%. Hasil analisis statistik Chi-square menunjukkan tidak terdapat hubungan yang signifikan antara umur dengan keluhan subjektif pada responden $(\mathrm{P}=0,138)$. Subjek dengan tingkat pendidikan yang rendah mengalami keluhan subjektif dengan proporsi yang lebih tinggi $(43,2 \%)$ dibanding yang memiliki tingkat pendidikan yang tinggi $39 \%$, namun tidak menunjukkan hubungan yang signifikan dengan keluhan subjektif $(\mathrm{p}=.0,796)$. Berdasarkan status gizi, terlihat bahwa keluhan subjktif lebih banyak dialami oleh subjek dengan status gizi lebih (gemuk) $(43,8 \%)$ dan normal $(41,9 \%)$ walaupun tidak berhubungan signifikan dengan keluhan subjektif $(p=0,840)$ dan $(\mathrm{p}=0,475)$. Subjek dengan durasi pemakaian antinyamuk $\geq 8$ jam perhari proporsinya lebih tinggi $(51,9 \%)$ mengalami keluhan subjektif dibanding subjek dengan durasi pemakaian $<8$ jam $(39,4 \%)$, namun secara statistik tidak menunjukkan hubungan signifikan dengan keluhan subjektif $(p=0,341)$. Frekuensi pemakaian antinyamuk dalam sehari pada subjek menunjukkan selisih proporsi yang tidak jauh berbeda antara subjek yang menggunakan $>1$ kali $(43,8 \%)$ dengan subjek yang menggunakan $\leq 1$ kali $(41,7 \%)$ untuk mengalami keluhan subjektif. Hal ini sejalan dengan tidak ditemukannya hubungan yang signifikan antara frekuensi pemakaian antinyamuk dengan keluhan subjektif $(p=1,000)$. Subjek yang menggunakan antinyamuk sesuai petunjuk justru memiliki proporsi yang lebih tinggi mengalami keluhan subjektif (44,7\%), dibanding subjek yang menggunakan antinyamuk tidak sesuai petunjuk (40,4 $\%$ ), dan secara statistik tidak terdapat hubungan signifikan dengan keluhan subjektif $(p=0,770)$. Keluhan subjektif justru lebih banyak terjadi pada subjek dengan tingkat pengetahuan yang baik $(61,5 \%)$ dari responden yang memiliki tingkat pengetahuan yang kurang $(29,8 \%)$.

Hasil analisis Chi square menunjukkan tingkat pengetahuan berhubungan signifikan dengan keluhan subjektif $(p=0,01)$, dan menjadi faktor protektif terhadap keluhan kesehatan subjektif. Jumlah jenis antinyamuk yang digunakan responden tidak berhubungan signifikan dengan timbulnya keluhan subjektif $(p=1,000)$. Keluhan subjektif cenderung dialami oleh subjek yang menyimpan antinyamuk kurang baik (49\%). Hasil uji statistik menunjukkan tidak ada hubungan bermakna antara cara penyimpanan antinyamuk dengan keluhan kesehatan subjektif $(p=0,262)$. Responden yang tidak menggunakan alat pelindung diri seperti sarung tagan dan masker saat kontak (aplikasi) antinyamuk cair dan antinyamuk bakar, cenderung mengalami keluhan kesehatan subjektif dibanding responden yang menggunakan alat pelindung diri, namun secara statistik tidak menunjukkan hubungan yang bermakna $(\mathrm{p}=0,188)$.

Hasil analisis multivariat regresi logistik didapatkan bahwa umur memiliki hubungan bermakna dengan keluhan kesehatan subjektif $\mathrm{p}=0,015)$. Umur yang lebih muda merupakan faktor protektif yang berarti bahwa pada populasi, subjek berumur muda berisiko lebih kecil 0,360 mengalami keluhan kesehatan subjektif $(\mathrm{RP}=0,36 ; 95 \% \mathrm{CI}=0,458-0,819)$. Tingkat pengetahuan berhubungan signifikan dengan keluhan kesehatan subjektif $(p=0,000)$. Sama halnya dengan umur, tingkat pengetahuan yang baik juga menjadi faktor protektif terhadap timbulnya keluhan kesehatan subjektif yang berarti bahwa pada populasi, tingkat pengetahuan baik berisiko lebih kecil 0,211 mengalami keluhan kesehatan subjektif $(\mathrm{RP}=0,211 ; 95 \% \mathrm{CI}=0,890-0,499)$. Durasi pemakaian antinyamuk berhubungan signifikan dengan keluhan kesehatan subjektif ( $\mathrm{p}=0,032$ ). Pada populasi, subjek dengan durasi pemakaian antinyamuk $\geq 8$ jam dalam sehari berisiko 2,96 kali untuk mengalami keluhan kesehatan subjektif dibanding subjek dengan durasi pemakaian $<8$ jam/hari $(\mathrm{RP}=2,96 ; 95 \% \mathrm{CI}=1,099$ 7,975).

Keluhan kesehatan subjektif pada pengguna antinyamuk terjadi oleh adanya bahan aktif pestisida yang terkandung di dalamnya. Bahan aktif pestisida dalam antinyamuk terdiri dari beberapa golongan yaitu piretroid, organofosfat dan karbamat. Bahan aktif pestisida golongan piretroid terdiri dari Sipermetrin, Transflutrin, D-Aletrin, Praletrin, dan Metoflutrin. Golongan karbamat bahan aktifnya adalah Propoxur, sementara golongan Organofosfat berbahan aktif Chlorpyrifos. Gejala yang yang ditimbulkan dari setiap golongan bahan aktif pestisida ada yang berbeda namun ada juga yang sama. Keracunan organofosfat menimbulkan gejala antara lain gerakan otot-otot tertentu, penglihatan kabur, mata berair, pusing, kejang-kejang, muntah-muntah, detak jantung menjadi cepat, mencret, sesak nafas, otot tidak bisa digerakkan dan akhirnya pingsan. ${ }^{8,} 9$ Gejala keracunan karbamat berupa keringat berlebihan, salivasi, lakrimasi, bronkokonstriksi, pinpoint pupil, peningkatan produksi lendir bronkhus, kram perut, muntah-muntah dan diare, serta bradikardi. 
Tabel 1. Karakteristik Responden di Kecamatan Indralaya

\begin{tabular}{|c|c|c|}
\hline Kategori & $\begin{array}{c}\text { Jumlah } \\
\text { (n) }\end{array}$ & $\begin{array}{c}\text { Persentase } \\
(\%)\end{array}$ \\
\hline \multicolumn{3}{|l|}{ Umur } \\
\hline Tua & 59 & 56,6 \\
\hline Muda & 77 & 43,4 \\
\hline \multicolumn{3}{|l|}{ Jenis Kelamin } \\
\hline Laki-laki & 36 & 26.5 \\
\hline Perempuan & 100 & 75,5 \\
\hline \multicolumn{3}{|l|}{ Tingkat Pendidikan } \\
\hline Rendah & 95 & 69,9 \\
\hline Tinggi & 41 & 30,1 \\
\hline \multicolumn{3}{|l|}{ Status IMT } \\
\hline Kurang & 13 & 9,6 \\
\hline Normal & 43 & 31,6 \\
\hline Lebih & 80 & 58,8 \\
\hline \multicolumn{3}{|l|}{ Durasi Pemakaian } \\
\hline$\geq 8$ jam & 27 & 19,9 \\
\hline$<8$ jam & 109 & 80,1 \\
\hline \multicolumn{3}{|l|}{ Frekuensi Pemakaian } \\
\hline$>1$ Kali & 16 & 11,8 \\
\hline$\leq 1$ Kali & 120 & 88,2 \\
\hline \multicolumn{3}{|l|}{ Menggunakan Sesuai Petunjuk } \\
\hline Tidak & 89 & 65,4 \\
\hline $\mathrm{Ya}$ & 47 & 34,6 \\
\hline \multicolumn{3}{|l|}{ Tingkat Pengetahuan } \\
\hline Kurang Baik & 84 & 61,8 \\
\hline Baik & 52 & 38,2 \\
\hline \multicolumn{3}{|l|}{ Personal Higiene Saat Kontak } \\
\hline Kurang Baik & 54 & 39,7 \\
\hline Baik & 82 & 60,3 \\
\hline \multicolumn{3}{|l|}{ Perilaku Penyimpanan } \\
\hline Kurang Baik & 51 & 37,5 \\
\hline Baik & 85 & 62,5 \\
\hline \multicolumn{3}{|l|}{ Pemakaian APD } \\
\hline Tidak & 93 & 68,4 \\
\hline Ya & 43 & 31,6 \\
\hline \multicolumn{3}{|l|}{ Keluhan Subjektif } \\
\hline Lelah & 27 & 19,9 \\
\hline Sakit Kepala & 30 & 22,1 \\
\hline Pusing & 26 & 19.1 \\
\hline Hilang Serela Makan & 19 & 13,9 \\
\hline Sesak Nafas & 14 & 10,3 \\
\hline Susah Bernafas & 13 & 9,6 \\
\hline Kejang Otot & 16 & 11,8 \\
\hline Tremor & 16 & 11,8 \\
\hline Gatal Pada Mata & 24 & 17,6 \\
\hline Mata Berair & 14 & 10,3 \\
\hline Penglihatan Kabur & 24 & 17,6 \\
\hline Gatal-gatal pada Kulit & 15 & 11,0 \\
\hline Keringat Berlebihan & 14 & 10,3 \\
\hline \multicolumn{3}{|l|}{ Keluhan Subjektif } \\
\hline Tidak ada & 57 & 41,9 \\
\hline Ada & 79 & 58,1 \\
\hline
\end{tabular}


Tabel 2. Hubungan Beberapa Faktor Risiko dengan Keluhan Subjektif pada Masyarakat Pengguna Insektisida Antinyamuk

\begin{tabular}{|c|c|c|c|c|c|c|c|}
\hline \multirow[t]{2}{*}{ No } & \multirow[t]{2}{*}{ Variabel } & \multicolumn{2}{|c|}{ Keluhan Subjektif } & \multirow[t]{2}{*}{ p-value } & \multirow[t]{2}{*}{$\mathbf{R P}$} & \multicolumn{2}{|c|}{$95 \% \mathrm{CI}$} \\
\hline & & Ada & Tidak ada & & & Lower & Upper \\
\hline \multirow[t]{3}{*}{1} & Umur & & & & & & \\
\hline & Tua & $20(33,9 \%)$ & $39(66,1 \%)$ & 0,138 & 0,705 & 0,461 & 1,079 \\
\hline & Dewasa & $37(48,1 \%)$ & $40(51,9 \%)$ & & & & \\
\hline \multirow[t]{3}{*}{2} & Tingkat Pendidikan & & & & & & \\
\hline & Rendah & $41(43,2 \%)$ & $54(56,8 \%)$ & 0,796 & 1,106 & 0,707 & 1,729 \\
\hline & Tinggi & $16(39 \%)$ & $25(61 \%)$ & & & & \\
\hline \multirow[t]{4}{*}{3} & IMT & & & & & & \\
\hline & Lebih & $35(43,8 \%)$ & $45(56,2 \%)$ & 0,840 & 0,926 & 0,437 & 1,959 \\
\hline & Kurang & $4(30,8 \%)$ & $9(69,2 \%)$ & 0,475 & 1,620 & 0,431 & 6,092 \\
\hline & Normal & $18(41,9 \%)$ & $25(58,1 \%)$ & & & & \\
\hline \multirow[t]{3}{*}{4} & Durasi Pemakaian & & & & & & \\
\hline & $\geq 8$ jam & $14(51,9 \%)$ & $13(48,1 \%)$ & 0,341 & 1,314 & 0,854 & 2,024 \\
\hline & $<8 \mathrm{Jam}$ & $43(39,4 \%)$ & $66(60,6 \%)$ & & & & \\
\hline \multirow[t]{3}{*}{5} & Frekuensi Pemakaian & & & & & & \\
\hline & $>1$ kali & $7(43,8 \%)$ & $9(56,2 \%)$ & 1,000 & 1,050 & 0,579 & 1,903 \\
\hline & $\leq 1 \mathrm{kali}$ & $50(41,7 \%)$ & $70(58,3 \%)$ & & & & \\
\hline \multirow[t]{3}{*}{6} & $\begin{array}{l}\text { Menggunakan sesuai } \\
\text { petunjuk }\end{array}$ & & & & & & \\
\hline & Tidak & $36(40,4 \%)$ & $53(59,6 \%)$ & 0,770 & 0,905 & 0,603 & 1,359 \\
\hline & $\mathrm{Ya}$ & $21(44,7 \%)$ & $26(55,3 \%)$ & & & & \\
\hline \multirow[t]{3}{*}{7} & Tingkat pengetahuan & & & & & & \\
\hline & Kurang & $25(29,8 \%)$ & $59(70,2 \%)$ & 0,01 & 0,484 & 0,327 & 0,716 \\
\hline & Baik & $32(61,5 \%)$ & $20(38,5 \%)$ & & & & \\
\hline \multirow[t]{3}{*}{8} & Personal higiene saat kontak & & & & & & \\
\hline & Buruk & $21(38,9 \%)$ & $33(61,1 \%)$ & 0,688 & 0,886 & 0,585 & 1,341 \\
\hline & Baik & $36(43,9 \%)$ & $46(56,1 \%)$ & & & & \\
\hline \multirow[t]{3}{*}{9} & Cara penyimpanan & & & & & & \\
\hline & Kurang & $25(49 \%)$ & $26(51 \%)$ & 0,262 & 1,302 & 0,880 & 1,926 \\
\hline & Baik & $32(37,6 \%)$ & $53(62,4 \%)$ & & & & \\
\hline \multirow[t]{3}{*}{10} & Pemakaian APD & & & & & & \\
\hline & Tidak & $43(46,2 \%)$ & $50(53,8 \%)$ & 0,188 & 1,420 & 0,876 & 2,301 \\
\hline & $\mathrm{Ya}$ & $14(32,6 \%)$ & $29(67,4 \%)$ & & & & \\
\hline \multirow[t]{3}{*}{11} & Jumlah Jenis Antinyamuk & & & & & & \\
\hline & $>1$ Jenis & $13(43,3 \%)$ & $17(56,7 \%)$ & 1,000 & 1,004 & 0,654 & 1,666 \\
\hline & $\leq 1$ jenis & $44(41,5 \%)$ & $62(58,5 \%)$ & & & & \\
\hline
\end{tabular}

Tabel 3. Hasil Analisis Multivariat Regresi Logistik Model Akhir

\begin{tabular}{lrrrrrrrr}
\hline Variabel & B & S.E & Wald & df & Sig. & Exp(B) & \multicolumn{2}{c}{ 95\% C.I. for EXP(B) } \\
\cline { 7 - 9 } & & & & & & & Lower & Upper \\
\hline Umur & -1.022 & .420 & 5.927 & 1 & .015 & .360 & .158 & .819 \\
Durasi pemakaian & 1.085 & .506 & 4.607 & 1 & .032 & 2.960 & 1.099 & 7.975 \\
Tingkat Pengetahuan & -1.557 & .440 & 12.522 & 2 & .000 & .211 & .089 & .499 \\
IMT_1 & -1.018 & .810 & 1.579 & 1 & .209 & .361 & .074 & 1.768 \\
IMT_2 & -.131 & .425 & .096 & 1 & .757 & .877 & .381 & 2.018 \\
Jumlah Jenis & -.185 & .483 & .146 & 1 & .702 & .831 & .323 & 2.141 \\
Tingkat pendidikan & .342 & .446 & .588 & 1 & .443 & 1.408 & .587 & 3.378 \\
Penggunaan APD & .435 & .495 & .772 & 1 & .380 & 1.545 & .585 & 4.079 \\
Frekuensi pemakaian & -1.131 & .889 & 1.617 & 1 & .203 & .323 & .056 & 1.844 \\
\hline
\end{tabular}

Gejala keracunan insektisida golongan karbamat antara lain, lakrimasi, salivasi, miosis, konvulsi, dan bisa terjadi kematian. ${ }^{10}$ Efek yang timbul dari keracunan piretroid adalah dapat mengganggu impuls saraf. ${ }^{11}$ Piretroid dapat menyebabkan alergi pada orang yang sensitif. ${ }^{4}$ Hasil penelitian Yuliani menunjukkan gejala keracunan yang dialami responden sebagai dampak penggunaan pestisida 
rumah tangga adalah sesak nafas $(44,54 \%)$, pusing $(25 \%)$, gatal $(12,5 \%)$, mual atau muntal $(25 \%)$, dan pingsan $(5,36) .{ }^{12}$ Dampak yang ditimbulkan oleh pajanan antinyamuk yang mengandung bahan aktif Transflutrhin terhadap induk mencit putih selama kehamilan dapat menyebabkan kelainan pada fetus mencit putih dan menurunnya berat badan induk mencit. ${ }^{13}$

Umur berhubungan signifikan dengan timbulnya keluhan kesehatan subjektif pada pengguna antinyamuk. Umur muda mengurangi resiko untuk mengalami keluhan subjektif. Umur yang semakin tua mengakibatkan penurunan rata-rata kadar kolinesterase, sehingga akan mempermudah terjadinya keracunan pestisida. ${ }^{14}$ Hasil dari beberapa penelitian juga menjelaskan hubungan antara umur dengan kejadian keracunan pestisida. Petani yang berumur $\geq 40$ tahun berisiko hampir 4 kali untuk mengalami keracunan pestisida dibanding petani yang berumur $<40$ tahun, semakin tua usia seseorang maka akan berisiko 2 kali lipat untuk mengalami gejala keracunan. ${ }^{14}$ Namun hasil penelitian lain menyebutkan tidak adanya hubungan signifikan antara umur dengan keracunan pestisida $(\mathrm{p}=0,944) .^{15}$

Tingkat pendidikan tidak berhubungan bermakna dengan keluhan subjektif pada responden penelitian ini. Pada prinsipnya, pendidikan diperlukan untuk mendapatkan informasi yang berguna dalam mencapai peningkatan kualitas hidup, diantaranya kesehatan.Pendidikan dapat mempengaruhi seseorang termasuk di dalamnya perilaku dan sikap, dimana semakin tinggi pendidikan seseorang maka akan makin mudah menerima informasi. Pemahaman yang baik terhadap bahaya pestisida yang terkandung dalam antinyamuk seharusnya akan mendorong seseorang untuk bersikap dan berperilaku baik dalam aplikasi dan penanganan antinyamuk sehingga dampak buruk bagi kesehatan dapat dihindari. Hasil penelitian ini sesuai dengan penelitian Wigati yang menyebutkan tingkat pendidikan tidak berhubungan dengan perilaku penggunaan antinyamuk $(p=0,655) .{ }^{16}$ Sementara beberapa hasil penelitian lain menyimpulkan bahwa tingkat pendidikan berhubungan signifikan dengan perilaku penggunaan insektisida rumah tangga $(\mathrm{p}=0,000) .{ }^{12}$ Pendidikan berkorelasi dengan perilaku penggunaan pestisida rumah tangga $(\mathrm{p}=0,01) .{ }^{12}$

Keluhan subjektif lebih banyak terjadi pada kelompok status gizi gemuk dibanding status gizi kurang dan gizi normal. Status gizi tidak menunjukkan hubungan yang bermakna dengan keluhan subjektif. Status gizi menentukan daya imunitas tubuh, dimana status gizi buruk berdampak pada menurunnya daya tahan tubuh dan meningkatnya kepekaan terhadap infeksi. Saat kondisi gizi buruk, protein di dalam tubuh amat terbatas, kondisi ini mengakibatkan pembentukan enzim kolinesterase akan terganggu. Berdasarkan teori ini dapat dikemukakan bahwa seseorang dengan status gizi yang baik akan mempunyai rata-rata kadar kolinesterase yang lebih tinggi. ${ }^{17}$ Responden penelitian ini mayoritas memiliki indeks massa tubuh dengan kategori gemuk, hanya sebagian kecil yang memiliki status gizi normal dan kurang, kemugkinan keadaan inilah yang menyebabkan tidak terdapatnya hubungan yang signifikan antara status gizi dengan timbulnya keluhan subjektif pada responden. Hasil analisis multivariat juga tidak menunjukkan hubungan bermakna status gizi dengan keluhan subjektif. Lama pajanan antinyamuk dalam sehari justru yang menjadi faktor risiko setelah dikontrol dengan beberapa variabel lainnya. Hal ini dapat mengungkap bahwa keluhan subjektif terjadi oleh karena durasi penggunaan antinyamuk yang lama ( $>8$ jam ) seharinya, bukan karena status gizi responden. Hasil penelitian ini berbeda dengan penelitian sebelumnya yang membuktikan adanya hubungan status gizi dengan kejadian keracunan pestisida, dimana responden dengan status gizi gemuk berisiko 5,87 kali lebih besar dibanding status gizi normal dan kurus ${ }^{14}$

Lama pemakaian antinyamuk berhubungan signifikan dengan keluhan kesehatan subjektif, dan menjadi faktor risiko dominan. Antinyamuk oles yang berbahan aktif golongan DEET seharusnya tidak boleh digunakan secara berulang setelah delapan jam pemakaian, artinya bahwa pajanan hanya dibatasi sampai 8 jam. DEET dapat berpenetrasi melalui kulit sehingga menimbulkan keracunan. Bahan aktif lainnya adalah golongan karbamat diantaranya propoxur yang dapat terkandung dalam antinyamuk bakar maupun semprot. Karbamat menimbulkan efek kerusakan pada syaraf dan diduga kuat sebagai zat karsinogenik. Selain DEET dan karbamat, piretroid adalah bahan aktif diantaranya transfultrin, $d$-alletrin, permetrin, dan sipermetrin. Meskipun piretroid memiliki toksisitas yang rendah pada manusia, karena tidak dapat terabsorpsi oleh kulit dengan baik, tetapi tetap saja dapat menimbulkan alergi pada orang yang sensitif ${ }^{4}$ Sama halnya dengan antinyamuk oles, lama pemakaian antinyamuk bakar, semprot, elektrik, seharusnya tidak melebihi 8 (delapan) jam pemakaian dalam satu hari. Responden menyebutkan biasanya akan mengoleskan kembali antinyamuk jika dirasakan efek antinyamuk sudah berkurang dalam menghindari gigitan nyamuk. Demikian halnya dengan antinyamuk bakar jika sudah habis terbakar maka diganti kembali. Hal ini yanng menyebabkan lama pajanan terhadap bahan aktif semakin meningkat, hingga pajanan pada tubuh meningkat pula. Hasil penelitian telah membuktikan hubungan signifikan antara lama pajanan pestisida dengan timbulnya keluhan kesehatan.Sejalan dengan penelitian ini, lama penyemprotan dalam sehari berhubungan signifikan dengan timbulnya keluhan pada petani penyemprot di Kecamatan Berastagi $(p=0.018){ }^{18}$

Frekuensi pemakaian antinyamuk tidak berhubungan signifikan dengan timbulnya keluhan kesehatan subjektif. Idealnya, frekuensi penggunaan antinyamuk akan menentukan intensitas pajanan pestisida terhadap tubuh responden. Intensitas pajanan 
juga akan menentukan timbulnya efek yang dapat berupa keluhan subjektif. Analisis secara deskriptif sebenarnya mengindikasikan adanya keterkaitan antara frekuensi penggunaan antinyamuk dengan keluhan subjektif, adanya kecenderungan bahwa frekuensi yang lebih dari 1 kali memiliki proporsi yang lebih tinggi mengalami keluhan subjektif. Seharusnya frekuensi penggunaan tidak melebihi 1 kali karena pajanan yang diperkenankan hanya sampai 8 jam per hari. Penelitian ini tidak dapat membuktikan hubungan signifikan antara frekuensi penggunaan antinyamuk dengan timbulnya keluhan subjektif kemungkinan disebabkan oleh karena adanya beberapa faktor lain yang lebih berpengaruh dalam menentukan terjadinya keluhan subjektif pada pengguna antinyamuk.

Penelitian yang mengkaji hubungan frekuensi penyemprotan pestisida dengan keluhan kesehatan menyebutkan bahwa frekuensi penyemprotan pestisida merupakan faktor risiko timbulnya keracunan pestisida. Petani penyemprot dengan frekuensi $\geq 2$ kali dalam seminggu berisiko 4,95 kali lebih besar dibanding yang $<2$ kali untuk mengalami keracunan pestisida. $^{14}$ Namun beberapa penelitian menjelaskan bahwa tidak terdapat hubungan signifikan antara frekuensi penyemprotan pestisida dengan timbulnya keluhan kesehatan pada petani. ${ }^{18,19}$

Jumlah jenis antinyamuk tidak berhubungan signifikan dengan keluhan subjektif pada responden. Responden menyebutkan sering menggunakan antinyamuk lebih dari satu jenis dalam menghindari gigitan nyamuk, terutama pada musim hujan karena populasi nyamuk yang meningkat. Bisa saja sudah menggunakan antinyamuk bakar atau semprot, tetapi juga masih menggunakan anti nyamuk oles dalam waktu bersamaan. Tetapi jika populasi nyamuk berkurang atau sedikit, responden menggunakan 1 jenis saja. Penggunaan insektisida rumah tangga sebagian besar lebih dari satu jenis insektisida dalam mengendalikan vektor nyamuk, diantaranya antinyamuk bakar, elektrik, aerosol, semprot, dan repellent. $^{20}$

Semakin banyak jenis pestisida yang digunakan semakin banyak pula bahan aktif yang masuk ke dalam tubuh. Efek keracunan yang ditimbulkan lebih besar jika dibandingkan dengan penggunaan satu jenis, oleh karena daya racun semakin kuat sehingga memberikan efek samping yang semakin besar ${ }^{17}$. Hasil penelitian Mualim menyebutkan bahwa jumlah jenis pestisida menjadi faktor risiko terjadinya keracunan pestisida organofosfat pada petani penyemprot hama. Petani yag menggunakan $\geq 3$ jenis pestisida sekali menyemprot berisiko 5,37 kali untuk mengalami keracunan dibanding yang menggunakan $<3$ jenis. ${ }^{14}$

Tingkat pengetahuan berhubungan signifikan dengan timbulnya keluhan kesehatan subjektif. Pengetahuan adalah hasil dari tahu, yang terjadi setelah orang melakukan penginderaan terhadap objek tertentu, yang terjadi melalui penca indera manusia, antara lain penglihatan, pendengaran, penciuman, rasa dan raba, dan sebagian besar pengetahuan manusia diperoleh melalui mata dan telinga. ${ }^{21}$ Roger menjelaskan pengetahuan mendasari terbentuknya perilaku seseorang, dimana perilaku yang didasari oleh pengetahuan biasanya lebih langgeng daripada perilaku yang tidak didasari oleh pengetahuan. Beberapa penelitian yang mengkaji perilaku penggunaan pestisida, menyebutkan bahwa pengetahuan berhubungan dengan perilaku penggunaan pestisida. ${ }^{16,21,22}$.Jadi pengetahuan tentang pestisida menjadi salah satu faktor penentu perilaku penggunaan pestisida. Perilaku Penggunaan pestisida dapat menentukan terjadi atau tidak terjadinya dampak atau gangguan kesehatan. Beberapa penelitian sebelumnya menyebutkan perilaku penggunaan pestisida berhubungan signifikan dengan timbulnya keluhan kesehatan pada petani hortikultura $(p=0,012)^{.23}$ Berbeda dengan penelitian ini, Minaka dkk mengemukakan pengetahuan tidak berhubungan secara signifikan dengan keluhan kesehatan pada petani hortikultura $(\mathrm{p}=0,72 ; \mathrm{p}=0,48) .{ }^{19}$

Status penggunaan antinyamuk sesuai petunjuk tidak berhubungan dengan terjadinya keluhan subjektif pada responden. Setiap jenis pestisida adalah racun, dosis yang semakin besar akan semakin mempermudah terjadinya keracunan. Dosis pestisida akan berpengaruh langsung terhadap timbulnya bahaya keracunan, hal ini ditentukan juga oleh lama pajanan. ${ }^{10}$ Secara toksikologi, jika semakin tinggi dosis yang digunakan maka semakin meningkat pula daya racun dari pestisida tersebut, yang dinyatakaan dengan hubungan dosis-respons (dose respon relationship). Hasil penelitian Mualim menyebutkan bahwa responden yang menggunakan pestisida tidak sesuai dosis yang ada pada petunjuk berisiko mengalami keracunan 6,46 kali lebih besar dibanding responden yang menggunakan sesuai petunjuk dosis ${ }^{14}$ Kajian lain menyebutkan bahwa tidak ada hubungan antara status penggunaan dosis pestisida sesuai petunjuk dengan terjadinya keluhan kesehatan $(\mathrm{p}=0,45){ }^{19}$

Penggunaan alat pelindung diri tidak berhubungan signifikan dengan keluhan subjektif. Responden yang menggunakan alat pelindung diri yang lengkap hanya ada 1,5\%, keadaan ini yang menyebabkan tidak terdapatnya hubungan bermakna antara kelengkapan alat pelindung diri dengan terjadinya keluhan subjektif pada responden. Pintu masuk pestisida ke dalam tubuh meliputi saluran pernafasan, saluran pencernaan melalui mulut atau tertelan, serta meresap atau penetrasi ke dalam kulit. ${ }^{9}$ Pestisida yang terkandung dalam antinyamuk sebagian besar masuk melalui saluran pernafasan, dan terserap oleh kulit. Antinyamuk bakar dan cair masuk melalui hidung, selain itu dapat juga masuk melalui kulit. Antinyamuk oles banyak diserap oleh kulit. Alat pelindung diri yang seharusnya digunakan ketika menyemprotkan antinyamuk cair terutama masker dan sarung tangan oleh karena pajanan terbanyak adalah 
lewat hidung dan kulit. Hasil penelitian ini berbeda dengan hasil penelitian Mualim yang menyebutkan penggunaan alat pelindung diri menjadi fakor risiko keracunan pestisida dimana petani $\mathrm{k}$ menggunakan alat pelindung diri yang tidak lengkap sewaktu kontak dengan pestisida berisiko 2,83 kali mengalami keracunan dibanding yang menggunakan alat pelindung diri yang lengkap. ${ }^{14}$

Cara penyimpanan insektisida antinyamuk tidak berhubungan dengan timbulnya keluhan subjektif pada responden. Hasil observasi terhadap cara penyimpanan antinyamuk didapatkan bahwa banyak responden yang menyimpan di sembarang tempat, seperti diatas televisi, dibawah meja atau lemari, bahkan ada yang disimpan dekat bahan makanan. Kondisi ini berpotensi menimbulkan pemajanan terhadap anggota keluarga, dan mencemari lingkungan rumah yang pada akhirnya berdampak terhadap timbulnya gangguan kesehatan. Namun demikian hasil penelitian sebelumnya juga menjelaskan bahwa cara penyimpanan pestisida tidak berhubungan dengan keluhan kesehatan $(p=0,89$; $\mathrm{p}=0,70) .{ }^{19}$ Seharusnya insektisida rumah tangga disimpan jauh dari jangkauan anak-anak, jauh dari makanan/bahan makanan. ${ }^{3}$

Pesonal higiene responden saat kontak dengan insektisida rumah tangga tidak berhubungan dengan keluhan kesehatan subjektif. Sebagian besar responden sudah memiliki personal higiene yang baik saat kontak dengan insektisida antinyamuk, tetapi masih banyak juga responden dengan personal higiene yang buruk. Responden tidak mencuci tangan atau bagian tubuh yang kontak dengan insektisida setelah aplikasi antinyamuk dan sebelum memegang makanan, peralatan rumah tangga, dengan demikian insektisda bisa masuk ke dalam pencernaan melalui mulut atau tertelan, serta meresap lewat kulit. ${ }^{9}$

\section{SIMPULAN}

Keluhan kesehatan subjektif akibat pajanan insektisida antinyamuk yang terbanyak dialami oleh responden adalah sakit kepala, lelah, pusing, hilang selera makan, sesak nafas, kejang otot, gatal pada mata, gatal pada kulit, penglihatan kabur. Durasi pemakaian insektisida antinyamuk merupakan faktor risiko terjadinya keluhan kesehatan subjektif pada pengguna antinyamuk, untuk itu perlu mengurangi durasi pemajanan dengan menggunakan kelambu pada saat tidur, sehingga penggunaan antinyamuk dibatasi hanya pada saat beraktivitas saja dengan situasi risiko gigitan nyamuk tinggi.

\section{UCAPAN TERIMA KASIH}

Penulis mengucapkan terima kasih kepada Lembaga Penelitian dan Pengabdian Kepada Masyarakat (LPPM) Universitas Sriwijaya yang telah membantu dalam pendanaan penelitian ini pada skema penelitian Sains Teknologi dan Seni (Sateks) Unsri tahun 2018. Ucapan terima kasih juga saya sampaikan kepada pihak Kecamatan Indralaya yang telah memberi perizinan pengambilan data di lapangan

\section{DAFTAR PUSTAKA}

1. Kementerian Kesehatan Republik Indonesia. Hasil Riset Kesehatan Dasar (RISKESDAS) 2013. Jakarta; 2013.

2. Widyasari WR, Ishak H, Birawida AB. Upaya Pencegahan Gigitan Nyamuk dengan Keberadaan Kasus Malaria. Media Kesehatan Masyarakat Indonesia. 2014;10 (3):145-150.

3. Raini M. Toksikologi Insektisida Rumah Tangga dan Pencegahan Keracunan. Media Penelitian dan Pengembangan Kesehatan. 2009; XIX (suplemen II):27-33.

4. Kusumastuti NH. Penggunaan Insektisida Rumah Tangga Antinyamuk di Desa Pangandaran, Kabupaten Pangandaran. Widyariset. 2014;17 (3):417-424.

5. Dahniar AR. Pengaruh Asap Obat Nyamuk Terhadap Kesehatan dan Struktur Histologi Sistem Pernafasan. Jurnal kedokteran Siyah Kuala. Jurnal kedokteran Siyah Kuala. 2011;11 (1):52-58.

6. Hendariani E. Identifikasi Residu Pestisida Klorpirifos dalam Sayuran Kol Mentah dan Kol Siap Santap. Media Kesehatan Masyarakat Indonesia. 2014;10 (3):154-159.

7. Purba IG, editor. Penggunaan Insektisida Antinyamuk pada Ibu Rumah Tangga di Kecamatan Indralaya. Seminar Nasional "Manajemen Bencana Kesehatan di Indonesia : Peran Perguruan Tinggi dalam Tangap Darurat Bencana"; 2016; Palembang Fakultas Kesehatan Masyarakat Universitas Sriwijaya; 2016.

8. Wudianto R. Petunjuk Penggunaan Pestisida. XVII ed. Depok: Penebar Swadaya; 2008. 87 p.

9. Djojosumarto P. Teknik aplikasi pestisida pertanian. Yogyakarta: Kanisius; 2008.

10. Kaloyanova FP, Batawi MAE. Human Toxicology of Pesticides. United States: CRC Press; 1991

11. Ecobichon DJ. Pesticide-Induced chronic toxicity: Fact or myth?. In: Agricultural health and safety. Workplace, environment, sustainability (edited CRC Press, Inc; 1995.

12. Yuliani TS, Triwidodo $\mathrm{H}$, Mudikdjo $\mathrm{K}$, Panjaitan NK, Manuwoto S. Perilaku Penggunaan Pestisida: Studi Kasus Pengendalian Hama Permukiman di Permukiman Perkotaan DKI Jakarta. Forum Pascasarjana. 2011;34 (3):195-212.

13. Ahmadin A, Dachriyanus D, Rosa M. Uji Efek Teratogen Anti Nyamuk Bakar yang Mengandung Transfluthrin Terhadap Fetus Mencit Putih. SCIENTIA. 2014;4 (2):46-60.

14. Mualim K, Setiani O, Hadisaputro S. Analisis Faktor Risiko yang Berpengaruh Terhadap Kejadian Keracunan Pestisida Organofosfat pada Petani Penyemprot Hama Tanaman di 
Kecamatan Bulu, Kabupaten Temanggung 2002. Jurnal Kesehatan Lingkungan Indonesia. 2002;1 (2):56-60.

15. Prijanto TB, Nurjazuli, Sulistiyani. Analisis Faktor Risiko Keracunan Pestisida Organofosfat Pada Keluarga Petani Hortikultura di Kecamatan Ngablak Kabupaten Magelang. Jurnal Kesehatan lingkungan Indonesia. 2009;8(2):73-78.

16. Susanti L, Wigati RA. Hubungan Karakteristik, Pengetahuan, dan Sikap, dengan Perilaku Masyarakat dalam Penggunaan Anti Nyamuk di Kelurahan Kutowinangun. 2012;40 (3):130-141.

17. Achmadi UF. Aspek Keselamatan Kerja Sektor Informal. Jakarta: Depkes RI 1992.

18. Mahyuni EL. Faktor Risiko dalam Penggunaan Pestisida Terhadap Keluhan Kesehatan pada Petani di Kecamatan Berastagi Kabupaten Karo 2014 KESMAS 2015;9(1):79-89.

19. Minaka IADA, Sawitri AAS, Wirawan DN. Hubungan Penggunaan Pestisida dan Alat Pelindung Diri dengan Keluhan Kesehatan pada Petani Hortikultura di Buleleng, Bali. Public Health and Preventive Medicine Archive; 2016. p. 94-103.

20. Meliyanie G, Wahyudi RI, Andiarsa D. Dampak Penggunaan Insektisida dalam Rumah Tangga Terhadap Keberadaan Larva/Pupa Aedes Aegypti di Kabupaten Kotawaringin Timur, Kalimantan Tengah. Journal Of Health Epidemiology and Communicable Diseases. 2016;2(1):14-18.

21. Prayitno P, Saam Z, Nurhidayah T. Hubungan Pengetahuan, Persepsi dan Perilaku Petani dalam Penggunaan Pestisida pada Lingkungan di Kelurahan Maharatu Kota Pekanbaru. Jurnal Kajian Lingkungan 2014;2(2):220-236.

22. Rario b, Kasto, Ritohardoyo S. Persepsi Dan Perilaku Petani Dalam Penanganan Risiko Pestisida Pada Lingkungan Di Kelurahan Kalampangan, Kecamatan Sabangau. Jurnal Manusia dan Lingkungan. 2005;12(1):43-52.

23. Kurniadi D. Faktor-Faktor Yang Berhubungan Dengan Keluhan Kesehatan Akibat Paparan Pestida Pada Petani Hortikultura di Desa Siulak Deras Mudik Kabupaten Kerinci. Menara Ilmu. 2018;12(20):13-18. 